\title{
Politics in African Wildlife Conservation: Wildlife Management Areas in Tanzania
}

\author{
Juan José del Valle Coello
}

Faculty Mentor: Dr. Maria Grosz-Ngatec, Department of African Studies Indiana University

\section{ABSTRACT}

Starting in the 1980's, an increasing number of international actors have advocated for a change in wildlife and resource conservation strategies, arguing for practices allowing for greater local management in a model known as "community-based conservation." Focusing on Tanzania, a country known for its expansive wildlife and game reserves, this investigation examines the adoption and implementation of legislation allowing for locally-administered Wildlife Management Areas (WMA's). This paper first documents the processes motivating the introduction of WMA legislation in Tanzania, then details the legislation's contents themselves and attempts to evaluate the social and political results as best it can, using a combination of sources including previously conducted research, promotional materials, and NGO publications.

Major aspects of legislation include the following: villages themselves choose to enter into WMA agreements with investors; investors collect the revenue and deliver it to the federal government, which in turn distributes it to villages and wildlife conservation programs; and village residents themselves determine how to allocate the revenue they receive. Results have been mixed; while many villages have benefitted from income received from participation in wildlife management, there have also been instances of coercion into participating, disputes between villages regarding WMA practices, and there has been a general lack of transparency in income collection and distribution. Furthermore, it is unclear to what extent recent legislation has actually given a greater degree of control to local government.

KEYWORDS: conservation, Tanzania, wildlife management, politics, conservation, African politics

\section{INTRODUCTION}

$\mathrm{I}^{\mathrm{n}}$ n his book Economic and Political Reform in Africa, anthropologist Peter Little quotes an elderly Kenyan Samburu woman as stating her community now "milks elephants as [they do] cows" (Little, 2013, p. 64), obtaining income from wildlife; he contrasts this with the experience of the residents of Narok County in southern Kenya, where disputes over control of protected areas have historically led to violence. Both cases are instances of a (relatively) new conservation model, "community-based conservation" or $\mathrm{CBC}$, which recognizes the importance of participation by local residents in conservation projects and the benefits these residents can obtain from such projects. Both Little's chapter on community-based conservation, as well as Milking the Rhino, a documentary about it, emphasize the contingent nature of its successful implementation, the heterogeneity of a community's actors, and the uncertainties involved in implementation; Little, furthermore, describes the highly politicized nature of conservation and the inequalities exacerbated by conservation efforts. These materials provide an overview of community-based conservation in a few settings (Namibia and Kenya) and allow for further questions to be asked. Topics of interest include, among various others, the intersection of conservation and development, the role of national vis-à-vis international actors, and actual changes in the places where new policies have been applied. This essay incorporates all these issues while seeking to address the following question: how have new approaches to wildlife conservation in Africa shifted power relations and beneficiaries? Using Wildlife Management Areas (WMA's) in Tanzania as a focus, this investigation finds that, at least in the Tanzanian context, community-based conservation approaches have formally created more participatory structures; however, benefits have remained ambiguous, and changes in power (here signifying influence on the outcomes of decisions) have not been very significant, though there might be potential for future devolution (transfer of control to lower/more local levels of government).

In his chapter, Little uses the term "community-based conservation" to refer to a broad set of policies and approaches to conservation and sustainable resource use. Other authors use this term somewhat differently; in the book African Wildlife and Livelihoods: The Promise and Performance of Community Conservation, researchers Edmund Barrow and Marshall Murphree (2001) categorize what they term "community conservation" into three categories: protected area outreach, collaborative management, and community-based conservation. "Protected area outreach" refers to the establishing of special regulations in areas surrounding protected areas (such as parks) in order to ensure the biological integrity of the protected area themselves, allowing wildlife to roam beyond park boundaries onto private or village land; "collaborative management" refers to the joint management of natural resources by conservation authorities and local users; and (Barrow's and Murphree's definition of) "community-based conservation" describes the transfer of formerly centralized control to local communities in order to promote sustainable use and livelihoods. This last category is also often labeled "community-based natural resource management” or CBNRM. These categories are rough 
delineations, and a project can include elements of more than one, but they do provide a useful way to understand an otherwise extremely broad array of diverse approaches and cases. Conservation (itself an extremely broad term) can apply to a great deal of different resources, but (as stated in their label) WMA's primarily concern wildlife conservation, particularly fauna, which has occupied a particularly large role in the African context. Tanzanian WMA's fall both under the CBNRM category and protected area outreach, as they are located primarily on the borders of official protected areas.

\section{A BRIEF HISTORY OF AFRICAN WILDLIFE CONSERVATION}

A discussion on African wildlife conservation must be situated in its historical context. Particularly salient in East and Southern Africa are protected areas such as national parks and game reserves, which are largely a direct inheritance of the colonial system. Both British and German colonizers in Africa created a system of game reserves with the exclusive purpose of recreational hunting and species conservation, being attracted by the "charismatic" and abundant wildlife there; this process entailed designating wildlife-rich areas, closing them off to native use and forcibly removing previous inhabitants (Jones, 2006, p. 485). In these artificially uninhabited areas, such as Krueger Park in South Africa and the Selous Game Reserve in Tanzania, white colonialists were able to hunt large land mammals for sport, while indigenous inhabitants that did the same (even for purposes of sheer survival) were punished as poachers (Jones, 2006).

The end of the colonial period and establishment of independent states brought about major changes in African politics and society, but there remained many aspects of the colonial legacy; one such aspect was wildlife conservation. Many national governments reneged on promises made to their citizenry, retaining game reserves or converting them to full-protection national parks, as wildlife had potential income benefits for governments (Jones, 2006). The conservation model maintained here was known as the "fortress," "command-and-control," or "fences and fines" model, whereby government attention was concentrated inside the park, with access restricted to local populations; however, territory outside the park fell outside of the purview of conservation (Little, 2013).

\section{A NEW APPROACH: COMMUNITY CONSERVATION}

Several factors came together by the early 1990's leading to a paradigm shift in conservation in Africa. At a time of rhetoric advocating for the retreat of state involvement and an increase in the role of private actors and good governance structures, calls for increased community involvement in conservation very much appealed to international donors, and since national governments underwent large cuts in spending as part of neoliberal reforms, community involvement could replace government patrolling (Little, 2013). Little attributes the rise of the $\mathrm{CBC}$ model to the rise of the neoliberal paradigm, and, though correct in recognizing this, he does overlook some other factors that also played a role. In particular, ecological science itself became increasingly cognizant of the relationship between humans and their environment, and approaches divorcing humans from ecosystems to be preserved (such as the previously mentioned fortress model) came under scrutiny (Berkes, 2004). In addition, the idea of sustainable development started gaining popularity around the same time, drawing attention to the mutually reinforcing relationship between ecological stability and positive development outcomes (Berkes, 2004). Specifically in Tanzania, poaching levels had halved elephant populations and nearly eliminated black rhinoceros (United Nations Development Program, 2015), and it was becoming increasingly apparent that the current fortress approach was not as effective as desired.

\section{WILDLIFE MANAGEMENT AREAS IN TANZANIA}

Calls for community involvement may be appealing in theory, but the reality on the ground often ends up quite differently. Officially, in Tanzania, villages themselves decide to organize and agree to form a WMA. The 1998 Wildlife Policy, together with the first WMA Regulations in 2002, detail the process by which villages do so (WWF, 2014). A group of villages agrees to set apart a certain amount of land for the WMA (withdrawing this land from other uses), form and register a community-based organization (CBO), and prepare legislation surrounding the WMA. The CBO then applies for Authorized Association (AA) status and can then formally enter into agreements with investors, which can include private companies and NGO's; partnership with outside entities can often be essential, given the lack of financial resources that many WMA villages command individually. WMA's can receive income from various tourist activities, including sport hunting (allowed in Tanzania), safari tours, photographic tours, and lodging on WMA grounds (WWF, 2014). Income from WMA activities is distributed in the following way: investors collect the revenue and deliver it to the federal government, which allocates $35 \%$ to its wildlife division and $65 \%$ to the WMA/AA. Half of this amount is divided evenly among the villages themselves, and the other half goes toward the maintenance of the WMA (including ranger salaries, for instance). The income received by villages can go toward a variety of causes, determined by CBO's: the construction of schools, health centers, and other infrastructure, aid for particularly vulnerable families, etc. (Sulle, Lekaita, \& Nelson, 2011).

While in theory villages enjoy significant autonomy and control in the WMA process, problems arise at all stages. Although officially villages themselves initiate and have to agree to form part of a WMA, there have been examples of coercion and manipulation on the part of government 
officials. For instance, Mayoka, one of the villages comprising Burunge WMA in northern Tanzania, had had disputes since 1984 with the authorities of Lake Manyara National Park, who stated that some land claimed by the village actually fell inside the park and thus prevented villagers from using it (Moyo, Ijumba, \& Lund, 2016); as such, Mayoka residents viewed efforts to include it into a WMA suspiciously as an attempt to remove its land. Another village to be included in Burunge WMA, Minjingu, had already received revenue from tourist activities before the WMA was established, and joining the WMA would actually reduce this income. As such, it entered into legal conflicts with other villages, as it refused to recognize its own membership (Moyo et al., 2016). The division of revenue among villages is actually a common issue of contention, as villages may set aside differing amounts of land and/or contribute different amounts of effort to the maintenance of the WMA (Moyo et al., 2016). Yet another issue in Burunge concerned the lack of consent by a minority pastoralist group, the Barabaig, in the WMA designation, resulting in the forced restriction of access to their traditional grazing land; here, it becomes apparent that the seemingly ubiquitous farmer-pastoralist disputes also occur in, and are reflected by, WMA arrangements (Sulle et al., 2011).

A significant structural challenge that WMA's face is a lack of income transparency. WMA's forgo income they could receive from farming or grazing on now protected land, and income from tourist activities typically cannot compensate for this adequately, at least in the short run. Furthermore, the central government itself suffers from a lack of transparency, and since it controls disbursement of revenue, villages have often received less than their due share (even though their due share they receive is not particularly high, given the revenue distribution described above) (WWF, 2014). Another problem villages experience in relation to WMA's consists of attacks by wildlife on their crops, livestock, or occasionally even their very inhabitants. WMA legislation specifically precludes mandatory compensation for such losses, and while payments in the form of consolation are permitted and sometimes made to victims, these are not consistent and do not typically make up for the financial loss (Moyo et al., 2016).

\section{BENEFITS OF WMA'S}

Wildlife Management Areas do provide benefits that should not be overlooked. First, they can generate some degree of income, and many member villages have actually made significant investments with it, such as the construction of new schools and dispensaries (WWF, 2014). Although many villages already benefitted from private tourist activities since the liberalization of tourism in Tanzania in the early 1990's, in other cases WMA's have introduced it to villages, which can bring a range of benefits, including even increased handicraft-making opportunities for women who can sell handicrafts to tourists (United Nations Development Program, 2015). Furthermore, WMA's can provide employment to local inhabitants as village game scouts. In one WMA, Enduimet, located in primarily Maasai territory, legislation allows pastoralists to graze their cattle on reserved land, an unusual arrangement that benefits both pastoralist and tourist activity (Sulle et al., 2011). Promotional materials for WMA's, such as USAID reports, even emphasize how gender relations have improved as a result of WMA's, with a more equitable distribution of revenue among villagers and female participation in WMA decision-making boards. Finally, the impact on wildlife has largely been positive, with increases in many species populations and increased mobility (which has, ironically, led to issues for villagers themselves, as some animals may be destructive to life and property) (WWF, 2014).

\section{REDISTRIBUTION OF DECISION-MAKING POWER}

Promotional materials about WMA's often try to portray them as "win-win" situations, citing participants' accounts that poaching is eliminated and villages enjoy inflows of resources. While most likely not fabricated, stories like these fail to acknowledge the often fraught political environment that WMA's can create or exacerbate, and they largely do not discuss how a village's situation may have worsened after a WMA was established (although, to their credit, such materials do consistently recognize that incomes are lower than expected). One particularly glaring omission is the change in the status of Game Controlled Areas (GCA's), a type of protected area. Before the establishment of WMA infrastructure, GCA's actually permitted all types of land use and settlement within their boundaries (forbidding only unlicensed hunting of wildlife); however, legislation on the foundation of WMA's changed this, prohibiting all agricultural and pastoral activity within GCA's (Sulle et al., 2011), thus functionally enclosing this land and removing its original users.

Ultimately, it is difficult to say that WMA's have significantly changed the power relations between local inhabitants, the centralized government, and outside companies and organizations. It is true that there is now a legislative template allowing villages to organize, which can provide them better negotiating power. However, as stated earlier, the national government (through the Wildlife Division) controls disbursement of payments, and these are not as transparent as desirable, although there is movement toward more direct control (WWF, 2014). Additionally, as many promotional materials themselves recognize, in negotiations with private investors, villagers often do not have the knowledge necessary to make informed and strategic decisions, allowing the company to take advantage of the village (WWF, 2014). The role of NGO's and international development agencies also merits discussion: as large and often well-financed players in African wildlife conservation and development projects, they provide a great deal of funding and thus have significant influence over the process. A report by Equator Initiative (a UNDP 
partnership with vulnerable communities) attributes the initiative for the MBOMIPA project, a pilot project for one of the first WMA's in Tanzania, to the United Kingdom's Department for International Development, claiming that this project ultimately resulted in the legislation creating WMA's (the 1998 Wildlife Policy of Tanzania) (United Nations Development Program, 2015).

\section{CONCLUSION}

Barrow and Murphree state that, in many cases of community conservation initiatives, planners and policymakers view participation "in an instrumental sense: as a means to achieve goals but not as a goal in its own right" (2001, p. 28). This description characterizes Tanzanian Wildlife Management Areas well. Tanzania's WMA's are an example of the attempted combination of conservation and development within the neoliberal conservation paradigm, which had already been introduced into Tanzania in the 1980's and 1990's; however, conservation goals dominate, and a rigid institutional structure reduces the opportunities that WMA's could provide. It can be argued that prioritizing conservation over development is not inherently unjust, but it can be ineffective if it does not successfully incentivize communities. Furthermore, local residents have benefitted from new economic opportunities in some communities but not in others, and the division of resources and revenue has caused disputes in some situations. It could logically be argued that the national government has in some situations actually extended its reach, as it now controls revenue from federally-registered WMA's. Of course, the case of Tanzania, while exemplifying several issues encountered in $\mathrm{CBC}$ in other areas (such as limited devolution of control), is not necessarily representative of all African countries, as contexts and outcomes have varied drastically. There is a growing movement advocating again for a renewed "fortress conservation" approach, criticizing CBC projects for their perceived lack of success in various regards (Jones, 2006). Such arguments, while based on fair criticisms, are premature: a current failure of $\mathrm{CBC}$ approaches to fairly involve communities does not necessarily mean that community involvement as a goal ought to be abandoned, as it is, still, a worthy goal.

\section{REFERENCES}

Barrow, E., \& Murphree M. (2001). Community Conservation: From Concept to Practice. In D. Hulme \& M. Murphree. (Eds.), African Wildlife and Livelihoods: The Promise and Performance of Community Conservation (pp. 25-38). Oxford, U.K.: James Currey Ltd.

Berkes, F. (2004). Rethinking Community-Based Conservation. Conservation Biology, 18(3), 621-630. doi:10.1111/j.1523-1739.2004.00077.x

Jones, S. (2006). A Political Ecology of Wildlife
Conservation in Africa. Review of African Political Economy, 33(109), 483-495.

doi:10.1080/03056240601000911

Little, P. D. (2013). Economic and Political Reform in Africa. Bloomington, IN: Indiana University Press.

Moyo, F., Ijumba, J., \& Lund, J. F. (2016). Failure by Design? Revisiting Tanzania's Flagship Wildlife Management Area Burunge. Conservation and Society, 14(3), 232-242. doi:10.4103/09724923.191160

Sulle, E., Lekaita, E., \& Nelson, F. (2011). From Promise to Performance? Wildlife Management Areas in Northern Tanzania. Tanzania Natural Resource Forum. Retrieved from http://tnrf.org/files/WMA summary.pdf

United Nations Development Programme. (2015). Matumizi Bora ya Malihai Idodi na Pawaga (MBOMIPA) Wildlife Management Area, Tanzania. Equator Initiative Case Study Series. Retrieved from http://equatorinitiative.org/images/stories/ winners/198/casestudy/case_1459269477.pdf

WWF. (2014). Tanzania's Wildlife Management Areas: A 2012 Status Report. WWF. Retrieved from http://www.twma.co.tz/uploads/WMA_Status_ Report_2012_Final.pdf 